\title{
Political Meritocracy and Its Betrayal
}

Franz Mang

Abstract:

Some Confucian scholars have recently claimed that Confucian political meritocracy is superior to Western democracy. I have great reservations about such a view. In this paper, I argue that so long as political meritocracy—-be it Confucian or non-Confucian—does not commit itself to the ideal of democracy, it has the dangerous tendency to become politically oppressive in the hands of authoritarian rulers. To illustrate the problem, I first revisit Isiah Berlin's classical discussion of the idea of positive liberty; he is deeply concerned about the abuse of this idea in the hands of dictators. Next, I examine Daniel Bell's model of meritocracy in relation to China's present form of governance. While Bell's model and China's present form of governance may not show political meritocracy at its best, they help to show that any version of political meritocracy that lacks a strong commitment to democracy tends to be political oppressive and, ultimately, may betray the ideal of political meritocracy. 


\section{Introduction}

With the growth of East Asia's political influence_-in particular, China's influenceConfucian scholars are once again contemplating how Confucianism might shape the world's future. ${ }^{1}$ And for those Confucian scholars who are particularly interested in political philosophy or political theory, the Confucian approach to statecraft has become all the more important, given the recent setbacks to democracy around the world. ${ }^{2}$ Some political philosophers, including Jiang Qing, Bai Tongdong, and Daniel Bell, have even claimed that Confucian political meritocracy is superior to liberal democracy. ${ }^{3}$ But is that really the case?

Political meritocracy, or simply meritocracy, can be understood as a political mechanism that selects and promotes leaders with superior ability and virtue. To achieve this aim, the relevant kinds of political rights are distributed on the basis of people's ability and virtue. In contrast, contemporary democracy, or simply democracy, can be understood as the ideal of rule by the people that is tied to the ideal of political equality; and the ideal of political equality, in turn, can be understood as the ideal of guaranteeing equal political standing of all citizens. ${ }^{4}$

Confucian political philosophers, in general, depart from the ideal of democracy as it is defined above. This is not to say that they want to dismiss democracy and get rid of popular

\footnotetext{
${ }^{1}$ See, e.g., Angle (2012); Bai (2012); Bell (2015); Chan (2014); Fan (2013); Jiang (2013); Kim (2018); Li (2009); Shin (2011); and Tan (forthcoming).

${ }^{2}$ For an instructive discussion of the recent setbacks to democracy, see Levitsky and Ziblatt (2018: 1-10).

${ }^{3}$ See, e.g., Jiang (2013: 27-32); Bai (2012; 2013a: 74-80); and Bell (2015: 27-43).

${ }^{4}$ For a similar interpretation of political equality, see, e.g., Anderson (1999: 312-13); Buchanan (2002: 710); Cohen (2003: 92). Of course, it can be reasonably argued that democracy is not necessarily associated with political equality; see Wall (2007).
} 
election. Yet, they generally think that it is of vital importance for the state, such as the Chinese state, to seek to combine Confucian political meritocracy - or simply Confucian meritocracyand democracy in some way. Confucian meritocracy refers to any kind of meritocratic political mechanism that is based on, or inspired by, Confucianism or Confucian values. For example, in ancient China, the imperial examination $(k e j u)$ adopted a Confucian examination syllabus for selecting officials.

For some Confucian scholars, while Confucian meritocracy needs to be endorsed in order to prevent the ills of liberal democracy and to make politics truly aim at the good, a robust commitment to the ideal of democracy, as the ideal is defined above, is either unnecessary or undesirable. For example, Jiang Qing has claimed that "the way ahead for China's political development is the Way of the Humane Authority and not democracy."5 To him, the main problem with Western democracy is that "there is nothing that can keep it in check." $\mathrm{He}$ proposes a specific type of tricameral legislature, which consists of the House of $R u$ (i.e., the House of Confucian scholars), the House of the Nation, and the House of the People. ${ }^{7}$ It is worth noting that, in Jiang's model of meritocracy, while the House of the People is democratically elected and the three houses are supposed to counterbalance each other, the House of $R u$, which consists of Confucian scholars not democratically chosen, enjoys "a permanent power of veto" over the laws proposed by the House of the People. ${ }^{8}$ Thus, Confucian meritocracy enjoys

\footnotetext{
5 Jiang (2013: 27).

${ }^{6}$ Jiang (2013: 29).

${ }^{7}$ Jiang (2013: 27-43).

${ }^{8}$ Jiang (2013: 41-42).
} 
supreme power. Jiang's model of meritocracy obviously departs from the ideal of democracy as defined above.

Unlike Jiang, Bai Tongdong is concerned about the danger of making Confucianism a national religion for any modern pluralistic society such as today's China. ${ }^{9}$ However, he agrees with other Confucian scholars that Western democracies are plagued with serious problems. Drawing on Mencius, he proposes a hybrid regime that gives Confucian meritocracy a central role to play. ${ }^{10}$ Such a hybrid regime consists of "a popularly elected chamber" and a Confucian chamber whose members "hold to the basic ideas of Confucianism" and are "selected through examination or recommendation." ${ }^{\text {11 }}$ He believes that "a strengthened voice of the Confucian in the legislature" can "promote good policymaking in key areas." 12 Yet, it is unclear whether for him the head of state and the highest officials should be democratically elected or meritocratically chosen. If he is right in claiming that "the shortcomings of the popular vote" are "deeply rooted" and "cannot be put to rights within the present democratic system,"13 then it is most likely that he would agree that the head of state and the highest officials need not be democratically elected. Thus, it appears that Bai's model of meritocracy also lacks a strong commitment to the ideal of democracy.

\footnotetext{
${ }^{9}$ Bai (2013b: 117-18).

${ }^{10}$ Bai (2012: 74-80).

${ }^{11}$ Bai (2012: 79).

${ }^{12}$ Ibid.

${ }^{13}$ Bai (2012: 78).
} 
As for Daniel Bell, Western democracy has attracted a lot of "blind faith." ${ }^{14}$ Since I will examine his model of meritocracy later, let me here describe only briefly how it departs from the ideal of democracy. Basically: he endorses a certain meritocratic and nondemocratic method for the selection of the highest political leaders, and, for him, this group of leaders make the most important political decisions on behalf of the people.

In short, Jiang, Bai, Bell, and some other Confucian meritocrats depart from the ideal of democracy as it is commonly understood, since they believe that

(a) the highest political leaders, including the head of a government, need not be democratically chosen, and that

(b) the exercise of political power by the leaders who are meritocratically chosen need not be severely restrained by the people.

I have great reservations about such a limited commitment to democracy. This is not because I consider political meritocracy as unjustified. ${ }^{15}$ Rather, it is because those Confucian meritocrats have overlooked the following important thing: political meritocracy-be it Confucian or non-Confucian-has the dangerous tendency to be politically oppressive in the hands of authoritarian rulers if it is not accompanied by a strong commitment to democracy. ${ }^{16}$

\footnotetext{
${ }^{14}$ Bell (2015: 61-62).

${ }^{15}$ In my view, some meritocratic practices are justifiable and may even be necessary for some societies (at least for a specific period of time). After all, democracy should not be pursued regardless of the concrete social and political conditions of a society. For a related discussion, see Hadenius and Teorell (2005).

16 This problem should not bother those Confucian scholars who hold a steadfast commitment to the ideal of democracy in seeking to combine democracy and Confucian meritocracy. Sungmoon Kim is one of these scholars; see Kim (2018, esp. Chs.1-2).
} 
To illustrate the problem, I will revisit Isaiah Berlin's classical discussion of the idea of positive liberty. I argue that what he intended to show are historical lessons about the abuse of the idea of liberty in the actual world, rather than a pure conceptual analysis of the idea of liberty. I submit that we should take these historical lessons seriously in understanding the practice of political meritocracy. Next, I examine Bell's model of meritocracy in relation to China's present form of governance. I have serious doubts about the legitimacy of any kind of political meritocracy that is not committed to the ideal of democracy.

\section{From political ideas to political oppression}

Confucian meritocrats might say that there is, of course, a gap between the ideal and the practice concerning political meritocracy, just as there is such a gap in relation to other political ideals. But, in my view, what is deeply worrying about political meritocracy cannot be fully grasped in terms of such a gap. As I will seek to demonstrate, there is a dangerous risk of the abuse of the idea of political meritocracy in the hands of authoritarian rulers. To illustrate the problem, let me revisit Berlin's discussion of positive liberty.

In his seminal essay "Two Concepts of Liberty," Berlin distinguishes between two different ways of understanding political liberty. ${ }^{17}$ Accordingly, there is the negative sense of liberty and there is the positive sense of liberty. Negative liberty is the freedom from constraints imposed by other agents, while positive liberty is the freedom to pursue and achieve desired goals. Notice that Berlin's analysis of the two concepts of liberty was accompanied with a historical account. To him, the negative sense of liberty has a relatively clear meaning. It

\footnotetext{
${ }^{17}$ Berlin (2002a).
} 
emerged and developed from the seventeenth to the early nineteenth centuries in some Western countries, in particular Britain and France, and it had long been associated with classical liberal thought. ${ }^{18}$ Positive liberty, though, was a more ambiguous concept. Throughout the history of philosophy, liberty (in the positive sense) had been taken to refer to autonomy, rational selfmastery, self-overcoming, and the Rousseauian idea of collective self-rule. ${ }^{19}$ Berlin pointed out that, in Rousseau's view, freedom is achieved through obedience to the general will. Thus, freedom involves "obedience to a law which we prescribe to ourselves," irrespective of our disparate preferences. ${ }^{20}$

It is this collective sense of freedom that deeply concerned Berlin; indeed, he considered that it had been historically central in politics. Importantly, whether freedom is understood in terms of Rousseau's general will or Kant's idea of rational autonomy, it invariably points to the transformation of the concept of the individual's will from what an individual actually desires to what an individual ought to desire. As such, an individual's goals or preferences should be regarded as unimportant, or simply irrelevant. Against this, Berlin advocated negative liberty, according to which an individual, at an empirical level, desires to be free from constraints and to act freely in his or her own way. To Berlin, negative liberty is definitely "more humane" than "the goals of those who seek in the great disciplined, authoritarian structures the ideal of 'positive' self-mastery."21

\footnotetext{
${ }^{18}$ Berlin (2002a: 170-71).

${ }^{19}$ Berlin (2002a: 179-212).

${ }^{20}$ Berlin (2002a: 183).

${ }^{21}$ Berlin (2002a: 216).
} 
Berlin was horrified by the political enforcement of positive liberty. In "A letter to George Kenna," he wrote:

What horrifies one about Soviet or Nazi practice is not merely the suffering and the cruelty.... What turns one inside out, and is indescribable, is the spectacle of one set of persons who so tamper and "get at" others that the others do their will without knowing what they are doing; and in this lose their status as free human beings, indeed as human beings at all. ${ }^{22}$

In other words, Berlin was horrified by the fact that positive liberty was easily exploited by politically powerful people, causing massive manipulation and dehumanization. To him, liberty misdefined is not liberty at all.

The history of totalitarian movements of the twentieth century has shown that Berlin's worries are far from theoretical. For example, Pol Pot (1925-1998), the general secretary of the Communist Party of Kampuchea from 1963 to 1981, frequently claimed that the Cambodian people should be "liberated." 23 Under his rule, the majority of the Cambodian people were relocated to the countryside to work on collective farms - the fulfilment of Pol Pot's ideal of liberation. Many of them died of malnutrition, starvation, or execution. It is estimated that around 1.5 million people perished in Pol Pot's prison-camp state. ${ }^{24}$ This is only one of the tragic examples of the betrayal of liberty, and it may be worth noting that Berlin's lecture on the two concepts of liberty was first delivered at Oxford in 1958, which was five years before the commencement of Pol Pot's leadership of the Cambodian Communist Party.

\footnotetext{
${ }^{22}$ Berlin (2002b: 339; emphasis added).

${ }^{23}$ Kiernan (1996: 31).

${ }^{24}$ Kiernan (1996: 9).
} 
Hence, what Berlin intended to offer was not a pure conceptual analysis of liberty. If we regard his analysis as purely conceptual, then we would not sense the kind of fear he had—which he thought all of us should have — about the possibilities for monstrous abuse of the concept of liberty. ${ }^{25}$ As some scholars have already suggested, political theorizing should have a historical dimension. ${ }^{26}$ From ahistorical conceptual analyses and thought experiments alone, we will not find any bloodstains, so to speak.

The kind of historical lessons that Berlin intended to draw about liberty can be called the betrayal of liberty: in the name of liberty, authoritarians and dictators have adopted highly oppressive measures for achieving "liberation" or "real freedom," causing widespread suppression of individual liberties and sometimes even the killing of people. ${ }^{27}$

I submit that we should take serious note of such historical lessons about political oppression in understanding the practice of political meritocracy. To be sure, political meritocracy and positive liberty are not the same thing, and they certainly differ in their practices. But, importantly, they might both appear to be attractive as theoretical concepts while their adoption in politics can be disastrous for the people who are subject to them. I propose, therefore, what can be called the betrayal of meritocracy, as follows:

\footnotetext{
${ }^{25}$ Berlin has also discussed the political persecution in Nazi Germany and Stalinist Russia; see Berlin (2002a: 5593, 336-44).

${ }^{26}$ For a useful discussion, see Smith (2000).

${ }^{27}$ In my view, rather than treating Berlin as an adamant opponent to positive liberty, it would be more appropriate to treat him as a resolute advocate for individual freedom against collectivism and totalitarianism. Here, I share Joshua Cherniss's and Henry Hardy's view (2018).
} 
In the name of political meritocracy, some rulers claim that the rule of the elite is necessary for maintaining law and order, for promoting people's welfare, or for enhancing national prestige. Hence, they adopt what they consider to be the necessary measures of suppressing individual liberties and, in some cases, even killing some of those who, they think, stand in the way of meritocracy. ${ }^{28}$

A note should be made to avoid misunderstandings. Some might think that what I am calling the "betrayal of meritocracy" need not be a problem for the rulers who adopt meritocracy, since these rulers may not care about the suppression of individual liberties and even the killing of some people; they are concerned, most fundamentally, with the success of their meritocratic rule. I do not necessarily deny this. Yet, in my discussion, the betrayal of meritocracy is a kind of betrayal of the subjects of meritocracy. It is a betrayal because the rulers who advocate meritocracy most commonly promise that each and every individual can benefit from it; but, in fact, this is seldom the case. To illustrate my point, I will discuss Daniel Bell's model of meritocracy in relation to China's present form of governance.

\footnotetext{
${ }^{28}$ Of course, suppression of individual liberties and the killing of people are not the same thing, but it is not uncommon for rulers who consider themselves meritocratic to do both things for a "better future" of their country. For examples of the killing of people on such grounds, please refer to the Chinese government's bloody crackdown on democracy protesters in Tiananmen Square on June 4, 1989, and the Khmer Rouge's purges in 1970s with the aim of creating “only pure Khmer people”; see Lim (2014: ch. 2) and Kiernan (2008: ch. 7), respectively.
} 


\section{Daniel Bell's model of political meritocracy}

To Daniel Bell, people have put a lot of blind faith in Western electoral democracy. ${ }^{29}$ Against electoral democracy, he proposed a meritocratic form of government that he called "the China Model," or, more precisely, "the vertical model of democratic meritocracy." While such a model of government adopts some democratic practices, it does not commit itself to the ideal of democracy as defined above. His model has three planks: democracy at the local level, experimentation with democratic practices below the top leadership level, and nondemocratic selection of leaders at the top. ${ }^{30}$ Drawing inspiration from Confucian ideas, he seeks to show that his model is both "morally desirable and politically realistic." 31

He develops his model of meritocracy in four steps. First, he criticizes liberal democracy ${ }^{32}$ To him, liberal democracy suffers a number of serious flaws, including the tyranny of the majority (i.e., the interests of minorities are either compromised or sacrificed), the tyranny of the minority (i.e., the wealthy class corrupts fairness in politics), the tyranny of the voting community (i.e., voters tend to ignore the basic interests of future generations and foreigners), and the tyranny of competitive individualists (i.e., democratic competition exacerbates social conflicts). So, he invites us to think about alternatives to electoral democracy-in particular, the prospects of political meritocracy.

\footnotetext{
${ }^{29}$ Those who have blind faith in electoral democracy he calls "democratic fundamentalists." See Bell (2015: 61-62).

${ }^{30}$ Bell (2015: 151-78).

${ }^{31}$ Bell (2015: 6-7).

${ }^{32}$ Bell (2015: 14-62).
} 
Second, he investigates the qualities that matter most in a meritocratic leader. ${ }^{33}$ To Bell, intellectual abilities, social skills, and moral virtue are the most important qualities that make a political leader suitable for governing a political community in the contemporary world. For the sake of China's future, he believes, certain things should be done to improve its meritocratic system. These measures include: a better examination system for testing people's intellectual abilities, an increase in the participation of women in political leadership, and an improved peerreview system for promoting (and demoting) political leaders.

Third, he examines the main difficulties with political meritocracy. ${ }^{34}$ To him, independent supervisory institutions, higher salaries, and moral education are all crucial for tackling the abuse of political power. It is also necessary to prevent the political hierarchies from becoming fixed. However, he admits that it is very difficult for political meritocracy to be fully legitimate. As a solution, he proposes that some democratic practices seem to be necessary for legitimizing meritocracy.

Finally, fourth, he argues that political meritocracy and democracy can be reconciled. ${ }^{35}$ His solution is the three-plank vertical model of democratic meritocracy. In arguing for this model, he rules out alternative models of democratic meritocracy, for he thinks that they are either politically unrealistic or insufficiently meritocratic. He claims that his own model, which retains meritocratic leaders at the top and seeks to improve itself through perfecting the peerreview system for selecting leaders, is both practicable and desirable. Interestingly, he suggests that the Chinese government may need to secure people's support by referendum, for reasons of

\footnotetext{
${ }^{33}$ Bell (2015: 63-109).

${ }^{34}$ Bell (2015: 110-50).

35 Bell (2015: 151-98).
} 
political legitimacy. He claims that it would be ideal to "specify a time period in the referendum itself—say, fifty years—-long enough to provide stability for the recruitment and training of meritocratically selected leaders." 36

To be fair to Bell, it should be noted that he has not claimed that societies should pursue political meritocracy through political oppression. In fact, he has pointed out that the Chinese state ought to become less oppressive and that the rule of law is of great importance for meritocracy to succeed. ${ }^{37}$ Yet, he believes that his model is most likely to work only in the context of a single-party state, such as China under the Chinese Communist Party. ${ }^{38}$

But it is exactly such a lack of commitment to democracy in Bell's model and in some other models of meritocracy that is deeply problematic from a moral point of view. In order to see the problems clearly, let us reflect on China's present form of governance. Bell and many other scholars have praised China's development in recent decades as an enormous success. Yet, whose success are they talking about?

\section{a. China's success-whose success is it?}

Bell—and many others who have expressed admiration for "China's success" — have not asked the above question. It might appear to be a silly question, as they might simply say that the success is, of course, China's and the Chinese people's. But the answer may not be so simple. It has been reported that a large number of Muslim Uyghurs in China are being "reeducated" in

\footnotetext{
${ }^{36}$ Bell (2015: 177).

${ }^{37}$ Bell (2015: 114, 191, 197).

${ }^{38}$ Bell (2015: 172).
} 
camps set up by the Chinese government. ${ }^{39}$ Suppose we had the opportunity to ask some of these Uyghurs: "To what extent are you enjoying China's success?" What sort of answer might we expect from them? Notice that the Chinese government doesn't simply treat these Uyghurs as foreigners or "losers" in China's development; the point of "reeducation" is exactly that they are being treated as part of the Chinese people and that, as some officials have claimed, they will benefit from China's development only by learning to become "civilized" —in a certain way. Yet, we seem to have every reason to regard such treatment of the Uyghurs as a case of ethnic oppression.

It is, in fact, rather easy to catalog examples showing that China's "success" has not been equitably shared. Notably, the 1994-2012 construction of the Three Gorges Dam, the world's largest hydropower project, led to the displacement of more than 1.4 million people and the destruction of more than a thousand villages by flooding. ${ }^{40}$ Advocates of political meritocracy, such as Bell, might argue that, despite a rather long list of moral problems with the Chinese government, the government is still doing the right thing for the people. As Bell has reminded us, several hundred million Chinese have been lifted out of poverty under the Chinese Communist Party’s leadership. ${ }^{41}$

\footnotetext{
${ }^{39}$ See, for example, a BBC report, "UN 'alarmed' by reports of China's mass detention of Uighurs (31 August 2018)," at https://www.bbc.com/news/world-asia-china-45364689. It is worth noting that the CCP has been adopting "thought reform" for the purposes of brainwashing since the 1950s, if not earlier. See the psychiatrist Robert Jay Lifton's research (1989).

${ }^{40}$ See Dawson and Farber (2012: ch. 2).

${ }^{41}$ Bell (2015: 36).
} 
Let us grant that poverty in China could not have been alleviated to such a remarkable degree without the leadership of the Chinese Communist Party (CCP). ${ }^{42}$ Nevertheless, Bell's kind of utilitarian reasoning can hardly justify the party's rule. For, even if utilitarianism as a moral theory is sound, it is definitely possible that the suffering of the victims under the party's rule has been so enormous that it outweighs all the happiness and pleasure that have been enjoyed by the (up-to-now) more fortunate Chinese people. ${ }^{43}$

In addition, there is a fundamental moral criticism of utilitarianism pertinent to our assessment of the party's political legitimacy; namely, that utilitarianism fails to take the separateness of individual persons seriously. ${ }^{44}$ Basically, it makes little sense to treat all Chinese people from the past to the present as a homogeneous entity that can enjoy "China's success." Would it not make more sense to treat each Chinese man or woman as an individual with human dignity?

Some might argue that it is pointless to insist that the moral legitimacy of a meritocratic regime needs to be assessed in terms of individuals' human dignity, for, after all, it is the total welfare of the subjects of meritocracy that counts. But, as a matter of fact, advocates of meritocracy usually do claim that meritocracy benefits each and every individual. Even for Bell, meritocracy should not concern the total welfare of the subjects of meritocracy alone. At one

\footnotetext{
${ }^{42}$ Note that it is always difficult to show that authoritarian rule is essential to economic development. For an indepth discussion, see Sen (1999: 148-51).

${ }^{43}$ Indeed, Bell has not said much about those who died because of the CCP's oppression or misrule. And for the current status of civil liberties in China, see, e.g., "Human Freedom Index" and "World Press Freedom Index" published in 2018.

${ }^{44}$ John Rawls has made this criticism. See Rawls (1999: 167).
} 
point, he juxtaposes Mencius and John Rawls to highlight the great importance for politicians to pay attention to the plight of the individuals of the least advantaged group in China. ${ }^{45}$

However, Bell cannot have it both ways; either he is concerned exclusively with the aggregate welfare of the people or he is concerned about the plight of the individuals of the least advantaged group in a country. He seems to be concerned exclusively with the aggregate welfare of the people in China. For in his assessment of the CCP's legitimacy, he has not asked any challenging question about the party's legitimacy from the perspective of the least advantaged groups in China, which may well consist of Muslim Uyghurs, Liu Xiaobo, and those students and workers who set up their tents at Tiananmen Square in $1989 .{ }^{46}$

\section{b. Full protection of the rule of law and civil liberties without democracy?}

To be fair to Bell, it should be noted that he has stressed the importance of the rule of law and of civil liberties. ${ }^{47}$ But there is a problem: how could the CCP safeguard civil liberties while maintaining its authoritarian rule? In defending meritocracy, Bell often talks about the CCP and Singapore's People's Action Party. ${ }^{48}$ However, there is little reason to think that these political parties are champions of civil liberties or of human rights.

\footnotetext{
${ }^{45}$ Bell (2015: 74).

${ }^{46} \mathrm{I}$ am referring to the crackdown on students and demonstrators at Tiananmen Square in 1989. In fact, Bell has conceded that the Chinese state should be more tolerant. He has also pointed out that the CCP sometimes was unnecessarily oppressive. See Bell (2015: 269 note 60). In my view, while theorists of meritocracy may complain about the "unnecessary" oppression executed by authoritarian rulers, the fact remains that political oppression and the killing of people tend to repeat themselves so long as authoritarian rulers wield absolute power.

${ }^{47}$ Bell (2015: 114, 191, 197).

${ }^{48}$ Bell (2015: 32-36).
} 
Bell sometimes uses Hong Kong as an example to illustrate how a political community can maintain the rule of law and fight corruption without democratic election of the head of a government and of the highest officials. ${ }^{49}$ This is not an entirely bad example. Indeed, before its handover to China in 1997, Hong Kong appeared to be an outstanding example of a free society governed by a meritocratic yet nondemocratic government. However, it should be noted, first, that Hong Kong before 1997 was not comparable with China or Singapore, for it was not under any single-party rule, whether within Hong Kong or from the United Kingdom. Second, since 1997, Hong Kong has been governed under the former Chinese leader Deng Xiaoping's formula of "one country, two systems." But the so-called two systems have been subject to the increasing political influence of the CCP's single-party rule, and, in this way, Hong Kong is becoming increasingly more comparable to China and Singapore. Notably, we are observing an obvious decline in the Hong Kong government's commitment to the rule of law. ${ }^{50}$ Hong Kong citizens' liberties, in particular freedom of speech and freedom of association, are being continuously reduced and threatened. Had Bell kept himself updated with recent developments in Hong Kong (he needed only to know a little more about Hong Kong's development since 1997), he would have been able to see that his ideal of a free society under a nondemocratic political meritocracy has been discredited.

Political meritocrats, in general, are very critical of liberal democracy. But they tend to overlook the fact that liberal democracy, coupled with the rule of law, has enabled many countries to enjoy sustainable economic and social development without suppressing civil

\footnotetext{
${ }^{49}$ Bell (2013: 2015: 117-18, 191)

${ }^{50}$ For a recent example, see a BBC report, "Fears over Hong Kong-China extradition plans (on 8 April 2019)" at: https://www.bbc.com/news/world-asia-china-47810723.
} 
liberties. ${ }^{51}$ Bell has not denied that, nor has he denied the importance of civil liberties, as I have pointed out. Yet if civil liberties are really important, then the Western democracies should take pride in what they have achieved. Why should they look up to any model of meritocracyConfucian or non-Confucian — that lacks a strong commitment to democracy?

Further, so long as a nondemocratic regime is determined to maintain its authority, it needs to suppress its political opponents in a systematic way. Thus, there develops what I call a cycle of oppression and resentment: violent oppression and humiliating punitive measures make many people resent the oppressors, and some of these people tend to retaliate violently, which, in turn, leads to more political oppression executed by the government in the name of social order and harmony, and so on, and so forth. ${ }^{52}$ A free society under a nondemocratic meritocracy seems to be a chimera.

\section{c. Nondemocratic political meritocracy_temporary or eternal?}

Some advocates of political meritocracy might claim that for China, Vietnam, and some other countries the premature adoption of democratic practices will do more harm than good, and that, for these countries, a nondemocratic meritocratic government is vital for achieving sustainable economic growth and social development. ${ }^{53}$ This line of argument is worth noticing,

\footnotetext{
${ }^{51}$ For discussions of the crucial importance of democracy for protecting individual liberties and preventing political oppression, see, e.g., Dahl (1989: esp. 77-79); Linz (1997: esp. 418-19); O’Donnell (2004); Sen (1999: 146-59, 227-49); and Shapiro (2003: 224-30).

${ }^{52}$ Such a cycle can be observed in China's Xinjiang, and in Iran, Saudi Arabia, Venezuela, etc.

${ }^{53}$ Bell has pointed out that the premature adoption of democracy could be harmful for a political community. See, for example, (2015: 15).
} 
and I can agree that, in some cases, democratization does more harm than good for a country's short-term development. However, there are certain difficult problems with the above argument.

First, as we have seen, so long as a meritocracy lacks a strong commitment to democracy, it tends to be politically oppressive. The moral loss that results from the suppression of civil liberties — and even the killing of heretics — can hardly be offset by economic growth and social development. Second, if it is correct to claim that liberal democracy coupled with the rule of law has enabled many countries to enjoy sustainable economic and social development without suppressing civil liberties, then there is very strong reason for any nondemocratic meritocracy to become fully democratized in the long term. ${ }^{54}$

In addition, a difficult problem exists concerning meritocratic leadership; namely, who is morally qualified to make meritocracy work? Bell is surely right in saying that if political meritocracy is desirable, then reliable mechanisms should be in place for choosing virtuous leaders. ${ }^{55}$ However, who will set up these mechanisms? Who will train future leaders? And who will devise regulations for meritocratic rule? It is extremely difficult to determine those who are qualified to shoulder these responsibilities on a long-term basis. ${ }^{56}$

For all of the above reasons, we should worry about the long-term performance of any government that lacks a strong commitment to democracy-be it meritocratic or not. ${ }^{57}$

\footnotetext{
${ }^{54}$ Sustainable economic growth is another strong reason for democratization. See, e.g., recent research by Acemoglu, Naidu, Restrepo, and Robinson (2019). In fact, some historians hold the view that, for its long-term development, China should become a liberal democratic regime. See, e.g., Yu (2018: 129).

${ }^{55}$ Bell (2015: 99-105).

${ }^{56}$ Bell appears to have a good deal of trust in the Chinese political leaders (see Bell 2015: 105, 112). However, he has not provided argument for that.

${ }^{57}$ For a related discussion, see Sen (1999: 51, 152; 2001: 188-9); and Drèze and Sen (1989: 264).
} 


\section{Must political meritocracy be politically oppressive?}

Of course, the pursuit of political meritocracy does not have to rely on oppressive measures - at least, that is the case in theory. However, what I have sought to demonstrate is that political meritocracy does have the tendency to become politically oppressive in actual politics, insofar as it does not commit itself to the ideal of democracy. Let me explain this point more clearly.

Facing citizens' oppositional political views and, in some cases, their resistance to the government, rulers - be they Confucian or non-Confucian — who do not commit themselves to democracy have to adopt a wide range of high-handed measures to sustain their authority. Many people consider Singapore and China as outstanding examples of political meritocracy, but few would deny that these are authoritarian regimes and that they are oppressing people's basic liberties in the face of political disagreements and political resistance.

Living under such regimes, citizens have every reason to complain that they are being betrayed by their rulers who claim to be meritocratic. The betrayal of meritocracy has two aspects. On the one hand, in the name of meritocracy, rulers may abuse power to satisfy their own interests, and, as a result, some citizens who have expected to benefit from meritocratic rule become victims of political oppression. On the other hand, even conscientious rulers may suppress citizens' basic liberties and, in extreme cases, kill some of them on the grounds of maintaining political meritocracy. As a result, there again arises what I have referred to as the vicious cycle of oppression and resentment: the victims of political oppression tend to react 
violently, as they cannot seek redress through democratic procedures and an independent judiciary, and their violent acts, inevitably, lead to further political oppression, and so on. ${ }^{58}$

In short, although political meritocracy, at least in theory, does not have to be politically oppressive, it does have the dangerous tendency to be politically oppressive so long as it lacks a strong commitment to the ideal of democracy.

\section{Concluding remarks}

Advocates of Confucian political meritocracy tend to compare political meritocracy at its best with liberal democracy at its most mediocre (or, simply, at its worst). But if my argument in this paper is, by and large, convincing, then it is extremely important for us to compare a political meritocracy and a liberal democracy at their worst.

Indeed, we do not have to deny that contemporary Western democracies should learn something from Confucianism; after all, it would seem naïve to think that all the deep-rooted problems facing liberal democracy can only be cured by increased democratic participation. Nevertheless, we should see that any form of political meritocracy that does not commit itself to democracy is constantly on a dangerous slide toward the betrayal of meritocracy.

Importantly, we should learn from history that most of the nondemocratic regimes-be they genuinely meritocratic or not — are politically oppressive, and that countless people have been persecuted, tortured, and/or killed in the name of national glory, social harmony, and the welfare of the majority. Think for a moment about China's future: We do not know exactly who

\footnotetext{
${ }^{58}$ Some scholars, including Guillermo O'Donnell (2004), have argued that a truly democratic rule of law is crucial for ensuring political rights, civil liberties, and mechanisms of accountability, and these things, in turn, affirm political equality of citizens and effectively prevent the abuse of political power.
} 
will suffer the betrayal of meritocracy - they could be some of us, some of our friends, and even some of our children, insofar as the Chinese political leaders who claim to be meritocratic fail to take seriously the ideal of democracy. 


\section{References}

Acemoglu, Daron, Suresh Naidu, Pascual Restrepo, and James A. Robinson. 2019. "Democracy Does Cause Growth.” Journal of Political Economy, 127(1): 47-100. https://economics.mit.edu/files/16686.

Anderson, Elizabeth. 1999. "What is the Point of Equality?" Ethics, 109: 287-337.

Angle, Stephen C. 2012. Contemporary Confucian Political Philosophy. Cambridge: Polity Press.

Bai, Tongdong. 2012. China: The Political Philosophy of the Middle Kingdom. London: Zed Books.

—. 2013a. “A Confucian Version of Hybrid Regime: How Does It Work, and Why Is It

Superior?" Pp. 55-87 in The East Asian Challenge for Democracy: Political Meritocracy in Comparative Perspective. Edited by Daniel A. Bell and Chenyang Li. Cambridge: Cambridge University Press.

—. 2013b. “An Old Mandate for a New State: On Jiang Qing’s Political Confucianism” Pp. 11328 in A Confucian Constitutional Order. Part II of A Confucian Constitutional Order: How China's Ancient Past Can Shape Its Political Future. Edited by Daniel A. Bell and Fan Ruiping; translated by Edmund Ryden. Princeton, NJ: Princeton University Press.

Bell, Daniel A. 2015. The China Model: Political Meritocracy and the Limits of Democracy. Princeton, NJ, and Oxford, UK: Princeton University Press.

Berlin, Isaiah. 2002a. “Two Concepts of Liberty.” Pp. 166-217 in Liberty: Incorporating Four Essays on Liberty. Edited by Henry Hardy. Oxford: Oxford University Press.

—. 2002b. "A Letter to George Kenna.” Pp. 336-44 in Liberty: Incorporating Four Essays on Liberty. Edited by Henry Hardy. Oxford: Oxford University Press.

Buchanan, Allen. 2002. "Political Legitimacy and Democracy.” Ethics, 112: 689-719.

Chan, Joseph. 2014. Confucian Perfectionism: A Political Philosophy for Modern Times. Princeton, NJ: Princeton University Press.

Cherniss, Joshua, and Henry Hardy. 2018. "Isaiah Berlin.” In The Stanford Encyclopedia of Philosophy. Summer 2018 edition. Edited by Edward N. Zalta. https://plato.stanford.edu/archives/sum2018/entries/berlin/. 
Cohen, Joshua. 2003. "For a Democratic Society.” Pp. 86-138 in The Cambridge Companion to Rawls. Edited by Samuel Freeman. Cambridge, UK: Cambridge University Press.

Dahl, Robert. 1989. Democracy and Its Critics. New Haven, CT: Yale University Press.

Dawson, Grant, and Sonia Farber, 2012. Forcible Displacement throughout the Ages: Towards an International Convention for the Prevention and Punishment of the Crime of Forcible Displacement. Leiden, Netherlands: Martinus Nijhoff Publishers.

Drèze, Jean, and Amartya Sen, eds. 1989. Hunger and Public Action. Oxford, UK: Clarendon Press.

Fan, Ruiping. 2013. “Confucian Meritocracy for Contemporary China.” Pp. 88-115 in The East Asian Challenge for Democracy: Political Meritocracy in Comparative Perspective. Edited by Daniel A. Bell and Chenyang Li. Cambridge, UK: Cambridge University Press.

Hadenius, Axel, and Jan Teorell. 2005. "Cultural and Economic Prerequisites of Democracy: Reassessing Recent Evidence.” Studies in Comparative International Development, 39(4): 87-106.

Jiang, Qing. 2013. “The Way of the Humane Authority: The Theoretical Basis for Confucian Constitutionalism and a Tricameral Parliament”; “The Supervisory System of Confucian Constitutionalism: Reflections on the Supervision of the State by the Academy"; “A Confucian Constitutionalist State: The Constitutional Role and Contemporary Significance of Republicanism under a Symbolic Monarch.” Chapters 1-3 in A Confucian Constitutional Order. Part I of A Confucian Constitutional Order: How China's Ancient Past Can Shape Its Political Future. Edited by Daniel A. Bell and Fan Ruiping; translated by Edmund Ryden. Princeton, NJ: Princeton University Press.

Kiernan, Ben. 2008. The Pol Pot Regime: Race, Power, and Genocide in Cambodia under the Khmer Rouge, 1975-79. Third edition. New Haven, CT: Yale University Press.

Kim, Sungmoon. 2018. Democracy after Virtue: Toward Pragmatic Confucian Democracy. New York: Oxford University Press.

Levitsky, Steven, and Daniel Ziblatt. 2018. How Democracies Die. New York: Crown Publishing. Li, Chenyang. 2009. "Where Does Confucian Virtuous Leadership Stand?” Philosophy East and West, 59(4): 531-36. 
Lifton, Robert Jay. 1989. Thought Reform and the Psychology of Totalism: A Study of "Brainwashing" in China. Chapel Hill, NC: University of North Carolina Press.

Lim, Louisa. 2014. The People's Republic of Amnesia: Tiananmen Revisited. New York: Oxford University Press.

Linz, Juan J. 1997. “Some Thoughts on the Victory and Future of Democracy.” Pp. 404-26 in Democracy's Victory and Crisis. Edited by Axel Hadenius. Cambridge, UK: Cambridge University Press.

O’Donnell, Guillermo. 2004. “The Quality of Democracy: Why the Rule of Law Matters.” Journal of Democracy, 15(4): 32-46.

Rawls, John. 1999. A Theory of Justice. Revised edition. Cambridge, MA: Harvard University Press.

Reporters Without Borders. 2019. 2019 World Press Freedom Index. https://rsf.org/en/ranking.

Sen, Amartya. 1999. Development as Freedom. Oxford, UK: Oxford University Press.

—. 2001. "Economic Development and Capability Expansion in Historical Perspective." Pacific Economic Review, 6(2): 179-91.

Shapiro, Ian. 2003. The Moral Foundations of Politics. New Haven, CT: Yale University Press.

Shin, Doh Chull. 2011. Confucianism and Democratization in East Asia. Cambridge, UK: Cambridge University Press.

Smith, Steven B. 2000. "Political Science and Political Philosophy: An Uneasy Relation.” Political Science and Politics, 33(2): 189-91.

Tan, Sor-hoon. Forthcoming. “Experimental Democracy for China: Dewey’s Method.” In Oxford Handbook of Dewey. Edited by Steven Feismire. Oxford, UK: Oxford University Press.

Vásquez, Ian, and Tanja Porčnik. 2018. Human Freedom Index 2018: A Global Measure of Personal, Civil, and Economic Freedom. https://object.cato.org/sites/cato.org/files/human-freedom-index-files/humanfreedom-index-2018-revised.pdf.

Wall, Steven. 2007. "Democracy and Equality.” The Philosophical Quarterly, 57: 416-38. 
Yu, Yingshi. 2018. Yuyingshi huiyilu 余英時回憶錄 [Yu Yingshi: A Memoir]. Taipei: Asian Culture 臺 北市: 允晨文化. 